\title{
ANALISIS DAMPAK PENERAPAN ESOP (EMPLOYEE STOCK OWNERSHIP PROGRAM) TERHADAP KINERJA PERUSAHAAN YANG TERDAFTAR DI BURSA EFEK INDONESIA
}

\author{
Lilis Susilawaty \\ ${ }^{1}$ Fakultas Ilmu Sosial dan Humaniora, Universitas Bunda Mulia \\ email: lsusilawaty@bundamulia.ac.id \\ Dewi \\ ${ }^{2}$ Fakultas Ilmu Sosial dan Humaniora, Universitas Bunda Mulia \\ email: dewiin840@gmail.com
}

\begin{abstract}
This study aims to determine whether the implementation of the ESOP share program (employee stock ownership program) can be an alternative strategy to minimize conflicts of interest that occur between shareholders and management because these differences in interests can affect the performance of the company. Sampling method used is purposive sampling method. Data analysis technique using Test Signal (Wilcoxon Signed Rank Test) which previously been done Test of Normality using Kolmogorov-Smirnov Test.The results showed that there are differences in sales growth before and after the implementation of ESOP (employee stock ownership program). While there is no difference in return on assets and net profit margin before and after the implementation of ESOP (employee stock ownership program).
\end{abstract}

Keywords:employee stock ownership program, return on assets, net profit margin, sales growth

\begin{abstract}
ABSTRAK
Penelitian ini bertujuan untuk mengetahuiapakah penerapan program kepemilikan saham ESOP (employee stock ownership program) dapat menjadi alternatif strategi untuk meminimalkan konflik kepentingan yang terjadi antara pemegang saham dan pihak manajemen karena perbedaan kepentingan ini dapat mempengaruhi kinerja perusahaan. Metode pengambilan sampel yang digunakan adalah metode purposive sampling.Teknik analisis data menggunakan Uji Tanda (Wilcoxon Signed Rank Test)yang sebelumnya telah dilakukan Uji Normalitas menggunakan Kolmogorov-Smirnov Test. Hasil penelitian menunjukkan bahwa terdapat perbedaan sales growth sebelum dan sesudah penerapan ESOP (employee stock ownership program). Sedangkan tidak terdapat perbedaan return on assets dan net profit marginsebelum dan sesudah penerapan ESOP (employee stock ownership program).
\end{abstract}

Kata Kunci :employee stock ownership program, return on assets, net profit margin, sales growth 


\section{PENDAHULUAN}

Menurut Husnan \& Pudjiastuti (p10, 2015), setiap perusahaan yang berbentuk Perseroan Terbatas yang sudah terdaftar di Bursa Efek Indonesia, sering terjadi pemisahan antara pengelola perusahaan (pihak manajemen, disebut juga sebagai agent) dengan pemilik perusahaan (pihak pemegang saham, disebut juga sebagai principal). Untuk itu, Perusahaan Terbatas yang sudah terdaftar di Bursa Efek Indonesia, tanggung jawab pemegang saham hanya terbatas pada modal yang disetorkan, dengan pengertian bahwa bila perusahaan tersebut bangkrut maka kekayaan pribadi pemegang saham tersebut tidak dijadikan jaminan untuk menutupi kerugian tersebut. Berbeda dengan pihak manajemen, tanggung jawab pihak manajemen adalah kehilangan jabatan dan pendapatan yang selama ini menjadi rutinitas para pihak manajemen.Perbedaan tersebut dapat memicu konflik yang disebut sebagai masalah keagenan (agency problems).

Husnan \& Pudjiastuti (2015, p1011) kembali menjelaskan bahwa tujuan normatif pengambilan keputusan keuangan oleh pihak manajemen adalah untuk memaksimumkan kemakmuran para pemegang saham.Namun keputusan pihak manajemen kerap merugikan pemegang saham dengan berbagai keputusan yang tidak baik seperti mengambil investasi yang tidak menguntungkan, menggunakan hutang yang terlalu banyak atau terlalu sedikit, menciptakan mekanisme yang mempersulit pengambilalihan perusahaan oleh perusahaan lain (takeover), dan sebagainya.Maka dari itu, penerapan program kepemilikan saham ESOP (employee stock ownership program) dapat menjadi alternatif strategi untuk meminimalkan konflik kepentingan yang terjadi antara pemegang saham dan pihak manajemen karena perbedaan kepentingan ini dapat mempengaruhi kinerja perusahaan.

Menurut Pugh (2000) dalam Isbanah (2015) menyebutkan bahwa aspek kepemilikan saham oleh karyawan (ESOP / employee stock ownership program) dapat menguatkan insentif manajer untuk membuat keputusan yang terbaik untuk kepentingan karyawan/pemiliknya.Pekerja juga dapat secara langsung meningkatkan profitabilitas melalui produktifitas tenaga kerja.Dapat dikatakan bila perusahaan menjalankan program kepemilikan saham oleh karyawan, hal ini juga akan meningkatkan efektifitas manajemen dalam menjalankan bisnisnya.

Indikator yang dapat digunakan untuk mengukur kemampuan perusahaan dalam menghasilkan laba adalah menggunakan rasio profitabilitas.Rasio ini mencerminkan kinerja perusahaan dalam mengukur efektivitas manajemen secara keseluruhan yang ditujukan besar kecilnya tingkat keuntungan yang diperoleh dalam hubungannya dengan penjualan maupun investasi (Fahmi, 2012, p68) dimana semakin baik rasio profitabilitas maka semakin baik menggambarkan kemampuan tingginya perolehan keuntungan perusahaan.Rasio profitabilitas yang digunakan adalah net profit margin dan return on assets, karena terdapat perbedaan hasil penelitian dengan penelitian sebelumnya.Selain itu, peneliti menambahkan sales growth yang diduga mengalami peningkatan pertumbuhan penjualan setelah mengadopsi ESOP (Wiratma \&Kristanto, 2010). 


\section{RERANGKA KONSEPTUAL}

Kinerja perusahaan merupakan isu penting terutama di era globalisasi yang informasinya dibutuhkan oleh para stakeholder perusahaan, dan informasi tersebut bisa dilihat dari laporan keuangan (Hutnaleontina \& Suputra, 2016). Indikator yang sering digunakan untuk menilai kinerja perusahaan ialah tingkat pengembalian (return) terhadap pemilik dan nilai perusahaan. Pencapaian return yang tinggi dan peningkatan nilai perusahaan dapat terwujud jika ada kerja sama yang baik antara pemegang saham (prinsipal) dan manajemen (agent).Namun dalam praktiknya, penyatuan kepentingan sulit dicapai. Penerapan ESOP merupakan salah satu cara untuk mengurangi perbedaan kepentingan antara para pemilik dan manajemen perusahaan (Hutnaleontina \& Suputra, 2016).

ESOP merupakan suatu jenis program pensiun yang dirancang untuk menerima kontribusi perusahaan pada suatu pengelola dana(fund) yang akan melakukan investasi pada saham perusahaan untuk kepentingan karyawan. Pendekatan ini merupakan program kepemilikan saham oleh karyawan yang diformulasikan oleh Kelso (Tim Studi Penerapan ESOP Emiten, 2002). Program ESOPs memberikan hak kepada karyawan untuk membeli sebagian saham perusahaan dalam suatu periode tertentu di masa mendatang dengan harga yang telah ditentukan pada saat opsi tersebut diberikan (Triana, 2009). Saat ini diIndonesia, banyak perusahaan yang mulai mengadopsi konsep employee stock ownership program (ESOP) dan management stock ownership plan (MSOP), terlihat dari 45 perusahaan paling likuid yang terdaftar di Bursa Efek Indonesia, 11 perusahaan diantaranya mengadopsi ESOP/MSOP (Aribawa, 2016).

Rosen et al (2005) dalam Aribawa (2010) menyimpulkan bahwa employee stock ownership plan (ESOP) dan management stock ownership plan (MSOP) didefinisikan sebagai program yang memberikan kesempatan untuk karyawan dan/atau manajemen untuk berhak memiliki sejumlah lembar saham perusahaan.Selain menghindari agency theory, penerapan ESOP merupakan salah satu strategi yang dijalankan perusahaan untuk meningkatkan loyalitas dan tanggung jawab karyawan atau manajemen terhadap perusahaan tersebut.

\section{Penelitian Terdahulu}

Beberapa penelitian yang pernah dilakukan dan menunjukkan bahwa pelaksanaan ESOP memiliki pengaruh positif terhadap kinerja keuangan dan nilai perusahaan antara lain dilakukan oleh Dien Triana(2009), Mardiantari dan Astika(2015), Hutnaleontina dan Suputra(2016), Aribawa(2016), Refka dan Jameleddine(2016), Wiratma dan Kristanto (2010), serta Ray(2016). Dalam penelitian yang dilakukan oleh Rachmawati (2013) menemukan hasil bahwa penerapan ESOP dapat meningkatkan kinerja perusahaan, hal ini dapat dilihat dari hasil perhitungan ROA dan NPM PT. Telkom Tbk. yang menunjukkan peningkatan yang signifikan, penerapan ESOP yang dilakukan juga dapat meningkatkan pertumbuhan penjualan yang dapat dilihat dari hasil perhitungan sales growth PT. Telkom Tbk. dan PT. PLN yang mengalami kenaikan yang cukup besar. Kedia dan Mozumdar (2002) menemukan bahwa alasan perusahaan memberikan opsi adalah untuk menghadapi kendala keuangan, 
memberikan insentif bagi peningkatan nilai perusahaan, dan untuk mempekerjakan serta mempertahankan karyawan. Hasil penelitian yang dilakukan oleh Hutnaleontina \& Suputra (2016) menyatakan bahwa semakin tinggi proporsi saham yang dihibahkan, maka semakin tinggi pula kinerja keuangan perusahaan.Temuan ini diperkuat oleh Maghraoui \& Zidai (2016) menunjukkan kepemilikan saham oleh karyawan memiliki hubungan yang positif terhadap kinerja perusahaan di Perancis.Ngambi \& Olume (2013) mengidentifikasi bahwa return on assets dapat digunakan untuk mengukur kinerja perusahaan yang berdampak setelah penerapan ESOP dilakukan perusahaan Republic of Cameroon.Penelitian di tahun 2013 yang dilakukan oleh Zhu et al juga menemukan bahwa para karyawan Huawei mendapatkan motivasi besar dan bekerja keras sehingga mampu meningkatkan produktifitas sehingga Huawei memiliki keuntungan yang signifikan karena menerapkan program kepemilikan karyawan (ESOP) terhadap para karyawannya.

Sebaliknya terdapat beberapa penelitian yang menunjukkan bahwa tidak terdapat pengaruh atau tidak ada peningkatan kinerja keuangan perusahaan setelah adanya pelaksanaan ESOP antara lain Bangun et al (2017), Kala et al (2015) dan Isbanah (2015) menemukan bahwa kepemilikan saham oleh karyawan (ESOP) tidak memiliki pengaruh terhadap kinerja keuangan perusahaan yang diukur dengan ROA, ROE, dan NPM karena dapat disebabkan oleh jangka waktu penelitian yang relatif pendek serta dapat pula disebabkan oleh porsi besarnya saham dari hasil penjatahan saham ESOP masih relatif kecil, yaitu karyawan berhak mendapatkan saham rata-rata hanya sebesar 5\% dari saham yang ditawarkan. Kala et al (2015) mengidentifikasi bahwa persentase modal yang dimiliki pemegang saham karyawan relatif tidak cukup mengubah sikap dan perilaku karyawan dengan cara meningkatkan kinerja perusahaan secara keseluruhan.

Berdasarkan beberapa penelitian yang dilakukan di beberapa negara yang telah mempunyai ketentuan dan pengalaman penerapan ESOP, disinyalir bahwa hal ini merupakan strategi positif yang dapat membuat perusahaan lebih kuat, memberi imbalan pada karyawan dan pada akhirnya meningkatkan nilai partisipasi pemilik perorangan dalam perusahaan (Tim Studi Penerapan ESOP Emiten, 2002).

\section{Net Profit Margin}

Menurut Isbanah(2015), Net Profit Margin (NPM) digunakan untuk mengukur perbandingan antara laba bersih dengan pendapatan. Rasio ini merupakan ukuran profitabilitas yang mengindikasikan net income yang dihasilkan dari setiap rupiah pendapatan dengan rumus sebagai berikut.

$$
\mathrm{NPM}=\frac{\text { Net Income }}{\text { Total Revenue }} \times 100 \%
$$




\section{Return On Assets}

Return on asset (ROA) digunakan untuk mengukur kemampuan perusahaan menghasilkan laba bersih berdasarkan tingkat asset tertentu(Isbanah, 2015).
Menurut Ngambi \& Oloume (2013), return on asset (ROA) juga mampu mengukur dampak ESOP terhadap peningkatan kinerja keuangan perusahaan.

$$
\text { ROA }=\frac{\text { Net Income }}{\text { Total Assets }} \times 100 \%
$$

\section{Sales Growth}

Sales growth merupakan pertumbuhan hasil penjualan perusahaan tahun ini jika dibandingkan dengan tahun sebelumnya.

$$
\text { Sales } \text { Growth }=\frac{\text { Sales }_{(t)}-\text { Sales }_{(t-1)}}{\text { Sales }_{(t-1)}}
$$

\section{PARADIGMA PENELITIAN}

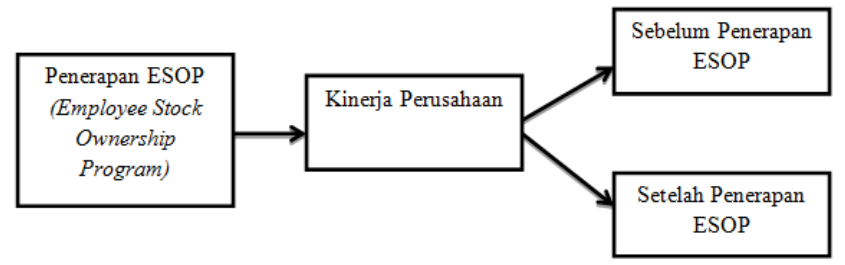

\section{METODE PENELITIAN}

Jenis penelitian ini adalah penelitian deskriptif, dengan pendekatan event study.Subjek penelitian adalah perusahaan menerapkan ESOP/MSOP yang terdaftar di Bursa Efek Indonesia tahun 2011 sampai 2015.Dalam pengambilan sampel penelitian dari populasi tersebut, peneliti menggunakan pendekatan non-probability random sampling dengan metode purposive sampling, dengan pertimbangan sebagai berikut.

- Merupakan perusahaan go public yang terdaftar di Bursa Efek Indonesia

- Merupakan perusahaan yang menerapkanESOP/MSOP(employee /management stock ownership program)
Sales growth dapat dihitung dengan rumus berikut: (Rachmawati, 2013)
- Memiliki dan menerbitkan laporan keuangan selama periode yang telah ditentukan oleh penulis yakni periode 2010 sampai dengan 2016.

- Merupakan perusahaan yang tidak mengalami aksi korporasilain selama periode pengamatan.

Dari pertimbangan diatas, maka yang memenuhi kriteria sampel adalah sebanyak 26 sampel penelitian.Data dalam penelitian ini menggunakan data sekunder yang diperoleh dari laporan keuangan perusahaan yang telah dikonsolidasi dan telah dipublikasikan di website Bursa Efek Indonesia yaitu www.idx.co.iddengan periode pengamatan yang digunakan adalah selama 3 (tiga) tahun yang terbagi menjadi 1 (satu) tahun sebelum dan 1 (satu) sesudah terjadinya penerapan 
ESOP(employee stock ownership program).Hal ini disebabkan ditemukan bahwa $90 \%$ dari karyawan yang menerima insentifdalam bentuk saham menjual saham tersebut sesaat setelah mereka exercise saham tersebut, jadi dapat dilihat bahwa program ESOP/MSOP ini memotivasi karyawan hanya pada waktu yang singkat (Brigham dan Ehrhardt, 2010).

\section{HASIL DAN PEMBAHASAN}

Tabel 1 Uji Normalitas(Kolmogorov-Smirnov Test)

\begin{tabular}{|c|c|c|c|c|c|c|c|}
\hline \multicolumn{8}{|c|}{ One-Sample Kolmogorov-Smirnov Test } \\
\hline & & B_ROA & A_ROA & B_NPM & A_NPM & B_SG & A_SG \\
\hline $\mathrm{N}$ & & 26 & 26 & 26 & 26 & 26 & 26 \\
\hline \multirow[t]{2}{*}{ Normal Parameters ${ }^{a, b}$} & Mean & 5.3881 & 4.3154 & 13.4223 & 10.0381 & 17.4973 & 11.0265 \\
\hline & Std. Deviation & 5.10859 & 4.68554 & 9.85696 & 9.20505 & 26.80826 & 23.46677 \\
\hline \multirow[t]{3}{*}{ Most Extreme Differences } & Absolute & .250 & .160 & .144 & .096 & .226 & .173 \\
\hline & Positive & .250 & .160 & .144 & .096 & .186 & .173 \\
\hline & Negative & -.153 & -.126 & -.100 & -.090 & -.226 & -.117 \\
\hline Test Statistic & & .250 & .160 & .144 & .096 & .226 & .173 \\
\hline Asymp. Sig. (2-tailed) & & $.000^{\circ}$ & $.087^{\circ}$ & $.173^{\circ}$ & $.200^{\mathrm{c}, \mathrm{d}}$ & $.001^{\circ}$ & $.043^{\circ}$ \\
\hline \multicolumn{8}{|c|}{ a. Test distribution is Normal. } \\
\hline \multicolumn{8}{|l|}{ b. Calculated from data. } \\
\hline \multicolumn{8}{|c|}{ c. Lilliefors Significance Correction. } \\
\hline \multicolumn{8}{|c|}{ d. This is a lower bound of the true significance. } \\
\hline
\end{tabular}

Berdasarkan hasil uji normalitas, diketahui bahwa data tidak berdistribusi normal sehingga dapat disimpulkan teknik analisis yang digunakan adalah Uji Tanda (Wilcoxon Signed Rank Test).
Hasil uji tanda dapat dilihat pada tabel 2 di bawah ini.

Tabel 2 Uji Tanda (Wilcoxon Signed Rank Test)

\begin{tabular}{|l|r|r|r|}
\hline \multicolumn{4}{|c|}{ Test Statistics $^{\mathbf{a}}$} \\
& $\begin{array}{l}\text { A_ROA- } \\
\text { B_ROA }\end{array}$ & $\begin{array}{c}\text { A_NPM - } \\
\text { B_NPM }\end{array}$ & A_SG - B_SG \\
\hline Z & $-1.181^{\mathrm{b}}$ & $-1.486^{\mathrm{b}}$ & $-2.629^{\mathrm{b}}$ \\
\hline Asymp. Sig. (2-tailed) & .238 & .137 & .009 \\
\hline \multicolumn{2}{|l|}{$\begin{array}{l}\text { a. Wilcoxon Signed Ranks Test } \\
\text { b. Based on positive ranks. }\end{array}$} & & \\
\hline
\end{tabular}

\section{Return On Assets}

Dari tabel 5.7 diketahui bahwa nilai pada Asymp. Sig. (2-tailed) sebesar0.238. Nilai pada Asymp. Sig. (2tailed) memiliki nilai yang lebih besar dari 0.05. Maka dapat disimpulkan bahwa bahwa Ho tidak ditolak yang artinya tidak terdapat perbedaanreturn on assetssebelum dan sesudah menerapkan ESOP.

Hasil penelitian menunjukan bahwa tidak terdapat perbedaan return on assets sebelum dan sesudah penerapan ESOP (employee stock ownership program).Hasil penelitian tidak sejalan dengan penelitian yang dilakukan oleh Rachmawati (2013), 
Ngambi \& Olume (2013) dan Mardiantari \& Astika (2015).

Namun hasil penelitian sejalan dengan Bangun et al (2017) dan Isbanah (2015) yang mengemukakan bahwa kepemilikan saham perusahaan oleh karyawan tidak memiliki pengaruh terhadap peningkatan return on assets. Hal ini disebabkan oleh besarnya porsisaham dari hasil penjatahan saham ESOP masih relatif kecil, yaitu karyawan berhak mendapatkan saham rata-rata hanya sebesar 5\% dari saham yang ditawarkan.Artinya, kepemilikan saham oleh karyawan hanya sebatas kepemilikan minoritas.

Maghraoui \& Zidai (2016) melihat kausalitas jangka panjang antara kepemilikan karyawan dan return on assets. Hal ini yang menyebabkan tidak terdapat perbedaan sebelum dan sesudah penerapan ESOP karena penelitian ini untuk melihat dampak penerapan ESOP jangka pendek.

\section{Net Profit Margin}

Dari tabel 5.7 diketahui bahwa nilai pada Asymp. Sig. (2-tailed) sebesar0.137. Nilai pada Asymp. Sig. (2tailed)memiliki nilai yang lebih besar dari 0.05. Maka dapat disimpulkan bahwa bahwa Ho tidak ditolak yang artinya tidak terdapat perbedaannet profit marginsebelum dan sesudah menerapkan ESOP.

Hasil penelitian menunjukan bahwa tidak terdapat perbedaan net profit margin sebelum dan sesudah penerapan ESOP (employee stock ownership program).Hasil penelitian tidak sejalan dengan penelitian yang dilakukan oleh Rachmawati (2013) dan Maghraoui \& Zidai (2016) yang menunjukkan kepemilikan saham oleh karyawan memiliki hubungan yang positif terhadap kinerja perusahaan di Perancis.

Namun hasil penelitian sejalan dengan hasil penelitian yang dilakukan Hartono \& Wibowo (2014) dan Kala et al (2015) yaitu tidak terdapat perbedaan net profit margin sebelum dan sesudah penerapan ESOP (employee stock ownership program). Kala et al (2015) mengidentifikasi bahwa persentase modal yang dimiliki pemegang saham karyawan relatif tidak cukup mengubah sikap dan perilaku karyawan dengan carameningkatkan kinerja perusahaan secara keseluruhan. Sedangkan Hartono \& Wibowo (2014) mengidentifikasi bahwa pemberian ESOP kepada karyawan akan meningkatkan kinerja perusahaan, akan tetapi pada saat yang sama ada yang harus dibayar untuk pelaksanaan ESOP ini sehingga dapat mengurangi laba perusahaan. Selain ini kurangnya pengetahuan dan pemahaman tentang program ESOP yang dimiliki karyawan juga menjadi salah satu alasan yang mempengaruhi keberhasilan pelaksanaan ESOP (Bapepam, 2002).

\section{Sales Growth}

Dari tabel 5.7 diketahui bahwa nilai pada Asymp. Sig. (2tailed)sebesar0.009. Nilai pada Asymp. Sig. (2-tailed) memiliki nilai yang lebih kecil dari 0.05. Maka dapat disimpulkan bahwa bahwa Ho ditolak yang artinya terdapat perbedaansales growthsebelum dan sesudah menerapkan ESOP.

Hasil penelitian menunjukan bahwa terdapat perbedaan sales growth sebelum dan sesudah penerapan ESOP (employee stock ownership program).Hasil penelitian sejalan dengan hasil penelitian yang dilakukan oleh Wiratma dan Kristanto (2010) dan Rachmawati (2013) yang menemukan 
hasil bahwa penerapan ESOP dapat meningkatkan pertumbuhan penjualan. Hasil perhitungan sales growth PT. Telkom Tbk. dan PT. PLN yang mengalami kenaikan penjualan yang cukup besar setelah menerapkan ESOP (Rachmawati, 2013). Penelitian di tahun 2013 yang dilakukan oleh Zhu et al juga menemukan bahwa para karyawan Huawei mendapatkan motivasi besar dan bekerja keras sehingga mampu meningkatkan produktifitas sehingga Huawei memiliki keuntungan yang signifikan karena menerapkan program kepemilikan karyawan (ESOP) terhadap para karyawannya.

Hasil penelitian ini memberikan informasi kepada pemegang saham, bahwa pemberian kepemilikan saham (ESOP) dapat diterapkan sebagai strategi jangka pendek dengan adanya kecenderungan peningkatan sales growth.Sebaiknya pemegang saham melihat program ini sebagai insentif yang diberikan kepada karyawan untuk meningkatkan kinerja atau produktivitas karyawan bukan sebagai jalan keluar untuk anti-takeover dari perusahaan lain ataupun sebagai sarana meningkatkan harga saham (Aribawa, 2010).

\section{PENUTUP}

Berdasarkan hasil dan luaran yang dicapai maka simpulan yang dapat dikemukakan adalah sebagai berikut :

1. Hasil penelitian menunjukkan bahwa tidak terdapat perbedaan kinerja perusahaan yang digambarkan oleh return on assets dan net profit margin sebelum dan sesudah penerapan ESOP (employee stock ownership program).

2. Hasil penelitian menunjukkan bahwa terdapat perbedaan kinerja perusahaan yang digambarkan olehsales growth sebelum dan sesudah penerapan ESOP (employee stock ownership program).

Berdasarkan hasil penelitian dan simpulan yang didapatkan maka saran yang dapat disampaikan adalah :

1. Hasil penelitian ini dapat memberikan informasi kepada pemegang saham, bahwa pemberian kepemilikan saham (ESOP/MSOP) dapat diterapkan sebagai strategi jangka pendek dengan adanya peningkatan sales growth.

2. Bagi peneliti lain dapat memperpanjang jangka waktu penelitian, karena dalam penelitian ini peneliti hanya melihat dampak peningkatan kinerja perusahaan jangka pendek 


\section{DAFTAR PUSTAKA}

Aribawa, Dwitya (2016). Analisis Nilai Perusahaan Pada Implementasi Program Kepemilikan Saham Pada Karyawan / Manajemen. Jurnal Ekonomi Dan Bisnis, Xix(3), 341-354.

Bangun et al. (2017).The Effect of Financial Leverage, Employee Stock Ownership Program and Firm Size on Firm Performance of Companies Listed in Indonesia Stock Exchange.International Business and Accounting ResearchJournal.Volume 1.Issue 2. Hal 82-98.

Brigham, E. F. dan M. C. Ehrhardt.. 2010. Financial Management: Theory \& Practice (13th Ed). Kentucky: South-Western College Pub.

Employee Ownership is an ESOP Right For Your Company. Diakses tanggal 06 Mei 2017 pada website

:Https://Www.Forbes.Com/Sit es/Aileron/2016/09/28/Employ ee-Ownership-Is-An-Esop-

Right-For-Your-

Company/\#7dfcc12a7f91

Fahmi, Irham. (2012). Analisis Kinerja Keuangan.Alfabeta : Bandung.

Fahmi, Irham. (2012). Manajemen Investasi : Teori Dan Soal Jawab. Salemba Empat : Jakarta.
Ferdinand, Augusty. (2014). Metode Penelitian Manajemen : Pedoman Penelitian untuk Penulisan Skripsi. Fakultas Ekonomika dan Bisnis Universitas Diponegoro. BP Undip, ISBN 979-704-254-5.

Hartono, Agus dan Wibowo, Alexander Jatmiko.(2014). Pengaruh Employee Stock Ownership Program Terhadapa Kinerja Perusahaan Publik Di Bursa Efek Indonesia.MODUS.Vol 26. No 1. Hal 85-91.

Hartono, Agus, \& Wibowo, Alexander Jatmiko (2014). Pengaruh Employee Stock Ownership Program Terhadap Kinerja Perusahaan Publik Di Bursa Efek Indonesia.Modus, Vol.26(1), 85-91.Issn 08521875

Hutnaleontina, Putu Nuniek, \& Suputra, I. Dewa Gede Dharma (2016). Pengaruh Penerapan Employee Stock Option Plan Pada Nilai Perusahaan Dengan Kinerja Keuangan Sebagai Variabel Intervening. E-Jurnal Ekonomi Dan Bisnis Universitas Udayana, 5.6, 1757-1784.Issn : 2337-3067

Isbanah, Yuyun (2015). Pengaruh Esop , Leverage , And Ukuran Perusahaan Terhadap Kinerja Keuangan Perusahaan Di Bursa Efek. Journal Of Research In Economics And Management (Jurnal Riset Ekonomi Dan Manajemen), Volume 15(1), Hal 28-41. 
Kala, K. Nithya, Poormina, D. S., \& Kala, D. K. Vidya (2015). Impact Of Employee Stock Options On Corporate Performance With Special Reference To Selected Financial Services Companies In India. Acme Intellects International Journal of Research In Management, Social Sciences \& Technology, 2939(9), 1-5.

Kedia, Simi, \& Mozumdar, Abon (2002). Performance Impact Of Employee Stock Options. Working Paper.

Https://Doi.Org/10.2139/Ssrn.3041 88

Maghraoui, Refka, \& Zidai, Jameleddine (2016). Effects Of Employee Ownership On The Performance Of French Companies Sbf120: Empirical Validation. Journal Of Accounting, Finance And Auditing Studies, 2(4), 195-217.

Mardiantari, Ni Putu Eka, \& Astika, Ida Bagus Putra (2015). Kinerja Keuangan Perusahaan Di Sekitar Peristiwa Pengumuman Esop Dan Pengaruhnya Pada Nilai Perusahaan. E-Jurnal Akuntansi Universitas Udayana.

Ngambi, Marcel T., \& Oloume, Frederic (2013). Employee Share Ownership And Firm Performance: Evidence From A Sample Of Cameroonian Firms Abstract: International Journal of Research In Social Sciences, 2(3), 48-55.
Peluang Karyawan Menjadi Pemegang Saham Perusahaan. Diakses tanggal 06 Mei 2017 di website :Http://Strategihukum.Net/Pelu ang-Karyawan-MenjadiPemegang-Saham-DalamPerusahaan

Rachmawati, Ika (2013). Pengaruh Penerapan Employee Stock Ownership Program (Esop) Terhadap Peningkatan Kinerja Perusahaan Ditinjau Dari Perspektif Ekonomi Islam.

Ray, Koustubh Kanti (2016). Employee Stock Option Plan And Firm Performance: A Quantile Regression Approach. Asian Journal Of Empirical Research, 6(6), 152-166. Https://Doi.Org/10.18488/Journal. 1007/2016.6.6/1007.6.152.166

Tim Studi Penerapan Esop Emiten Perusahaan Publik Di Pasar Modal Indonesia. (2002). Studi Tentang Penerapan Esop (Employee Stock Ownership Plan) Emiten Atau Perusahaan Publik Di Pasar Modal Indonesia, 1-103.

Wiratma, Tomy dan Kristanto, Rudi Suryo .(2010). Analisis Pengaruh ESOP (Employee Stock Ownership Program) Terhadap Kinerja Perusahaan di Bursa Efek Indonesia. Jurnal Prestasi. Vol 6. No 1. Hal 120-135. ISSN 1411-1497

Zhu et al. Employee Stock Ownership Plans and Their Effect on 
Versi Online: http://journal.ubm.ac.id/

Hasil Penelitian
Jurnal Manajemen Vol.13(2) : 85-191. Th. 2017 ISSN: 1907-0896
Productivity: The Case of Huawei.International Journal of Business and Management Invention.Volume 2 Issue 8.
PP.17-22. ISSN (Online): 2319

- 8028, ISSN (Print): 2319 $801 X$ 